\title{
Neurological Complications of Pulmonary Embolism: a Literature Review
}

\author{
Parth V. Desai ${ }^{1}$. Nicolas Krepostman ${ }^{2} \cdot$ Matthew Collins ${ }^{2} \cdot$ Sovik De Sirkar $^{2} \cdot$ Alexa Hinkleman $^{2} \cdot$ Kevin Walsh $^{2}$. \\ Jawed Fareed ${ }^{3} \cdot$ Amir Darki $^{1}$ (i)
}

Accepted: 8 July 2021 / Published online: 20 October 2021

(c) Springer Science+Business Media, LLC, part of Springer Nature 2021

\begin{abstract}
Purpose of Review The present review discusses in-depth about neurological complications following acute venous thromboembolism (VTE).

Recent Findings Intracranial hemorrhage, acute ischemic cerebrovascular events, and VTE in brain tumors are described as central nervous system (CNS) complications of PE, while peripheral neuropathy and neuropathic pain are reported as peripheral nervous system (PNS) sequelae of PE. Syncope and seizure are illustrated as atypical neurological presentations of PE. Summary Mounting evidence suggests higher risk of venous thromboembolism (VTE) in patients with neurological diseases, but data on reverse, i.e., neurological sequelae following VTE, is underexplored. The present review is an attempt to explore some of the latter issues categorized into CNS, PNS, and atypical complications following VTE.
\end{abstract}

Keywords Pulmonary embolism $\cdot$ Venous thromboembolism $\cdot$ Neurological complications $\cdot$ Cerebrovascular disease

$\begin{array}{ll}\text { Abbreviations } \\ \text { ACCP } & \text { American College of Chest Physicians } \\ \text { ASA } & \text { Atrial septal aneurysm } \\ \text { ASD } & \text { Atrial septal defect } \\ \text { CDT } & \text { Catheter-directed thrombolysis } \\ \text { CNS } & \text { Central nervous system } \\ \text { CS } & \text { Cryptogenic stroke } \\ \text { CTEPH } & \begin{array}{l}\text { Chronic thromboembolic pulmonary } \\ \text { hypertension }\end{array} \\ \text { DIC } & \text { Disseminated intravascular coagulation } \\ \text { DOAC } & \text { Direct-oral anticoagulant } \\ \text { DVT } & \text { Deep vein thrombosis }\end{array}$

This article is part of the Topical Collection on Neurology of Systemic Diseases

Amir Darki

amirdarki@gmail.com; ADARKI@lumc.edu

1 Department of Cardiovascular Medicine, Loyola University Medical Center, Maywood, IL 60153, USA

2 Departmet of Internal Medicine, Loyola University Medical Center, Maywood, IL 60153, USA

3 Department of Pathology and Laboratory Medicine and Department of Pharmacology and Neuroscience, Health Science Division, Cardiovascular Research Institute, Hemostasis and Thrombosis Research Division, Loyola University, Maywood, IL 60153, USA
ESUS Embolic stroke of uncertain etiology

ICH Intracranial hemorrhage

IVC Inferior vena cava

LMWH Low molecular weight heparin

MI Myocardial infarction

MTS May-Thurner syndrome

ORBI Outpatient bleeding risk index

PE Pulmonary embolism

PESI Pulmonary Embolism Severity Index

PFO Patent foramen ovale

PNS Peripheral nervous system

PTS Post-thrombotic syndrome

RLS Right-to-left shunt

SARS Severe acute respiratory syndrome

SUCRA Surface under the cumulative ranking curve

TS Trousseau syndrome

VKA Vitamin K antagonist

VTE Venous thromboembolism

\section{Introduction}

Venous thromboembolism (VTE), a term collectively referred for deep vein thrombosis (DVT) and pulmonary embolism (PE) is often underdiagnosed and potentially life threatening. This preventable medical condition is the 
third most common cause of cardiovascular mortality [1], with an estimated incidence of 1-2 cases per 1000 persons ( $\sim 900,000$ cases) per year in the USA [2]. According to a 2016 study, annual incident VTE is estimated to cost the US healthcare system about \$7-12 billion (2014 US dollars) annually [3]. Venous stasis, hypercoagulability, and endothelial injury (commonly known as Virchow's triad) are key factors underlying VTE pathophysiology [4]. Numerous acquired and inherited risk factors (advancing age, obesity, recent surgery or hospitalization, active cancer, trauma or fracture, immobility or paralysis, pregnancy or puerperium in women, oral contraceptives or hormonal therapy, and several inherited thrombophilia) predispose individuals to thrombosis [2].

VTE as a sequela of neurologic disease is widely established. Various neurological disorders contribute to immobility and hypercoagulability. The incidence of VTE within the first 3 months after acute ischemic stroke is $15 \%$ compared to $0.2 \%$ in the general population [5]. Compared to the thrombotic consequences of neurologic disease, the neurologic complications of VTE are less studied. In this review article, we sought to discuss the neurological sequela of VTE.

\section{Classification, Severity, and Complications of Venous Thromboembolism}

DVTs are classified based on location and etiology. Lower limb DVT with thrombi proximal to the popliteal trifurcation is labeled as proximal whereas below is identified as distal DVT. Upper limb DVT is far less common than lower extremity but still account for $10 \%$ of DVTs, predominantly related to indwelling central venous catheters and cardiac leads from pacemakers and defibrillators [6]. The etiology of DVT as provoked (with underlying trigger) versus unprovoked (without an identifiable trigger) and temporary (reversible trigger) versus permanent (irreversible trigger) [7] helps guide duration of treatment and risk of recurrence. [8]. Although majority of distal DVT spontaneously resolve with minimal symptoms, significant morbidity can be caused by thrombi extending into popliteal, femoral, and other proximal veins $[9,10]$.

Common complications of DVT include post-thrombotic syndrome (PTS), PE, and sudden death [11]. If left untreated, there is a 50\% chance that proximal DVT will cause symptomatic PE within 3 months [10, 12]. PTS occurs in about $30-50 \%$ DVT patients which sometimes result in lifelong limb pain, swelling, heaviness, edema, telangiectasias, lipodermatosclerosis, and leg ulcers [13-15]. In patients with proximal DVTs, $30-40 \%$ are likely to develop PE, while $70 \%$ of patients with PEs have concomitant DVT [16]. Estimate suggests that 10-30\% people die of VTE within 1 month of diagnosis with about a quarter of people presenting as sudden death [2]. Data also suggests about one third (33\%) of the patients with VTE would have recurrence within 10 years of initial diagnosis [2].

Acute PE is classified per the American Heart Association (AHA) and European Society of Cardiology (ESC) guidelines into massive, sub-massive (high/intermediate risk), and low risk (Table 1) based on the hemodynamic stability and end-organ damage (elevated cardiac biomarkers and right ventricular strain) $[17,18]$. This classification helps to stratify risk of decompensation and guides in management decisions [17-19]. Pulmonary Embolism Severity Index (PESI) and simplified PESI (sPESI) are incorporated into the ESC guidelines for further risk stratification [20, 21].

While acute massive PE can cause immediate cardiorespiratory failure resulting in death, longstanding PE can cause chronic thromboembolic pulmonary hypertension

Table 1 Criteria for risk- stratification of acute pulmonary embolism

\begin{tabular}{|c|c|c|c|c|c|}
\hline & Risk Profile & $\begin{array}{l}\text { Shock or } \\
\text { Hypotension }\end{array}$ & $\begin{array}{l}\text { RV } \\
\text { Dysfunction }\end{array}$ & $\begin{array}{l}\text { Cardiac } \\
\text { Biomarkers }\end{array}$ & $\begin{array}{l}\text { PESI Class } \\
\text { III-V or sPESI } \\
\geq 1\end{array}$ \\
\hline \multirow{4}{*}{ ESC } & High & + & + & + & + \\
\hline & $\begin{array}{l}\text { Intermediate- } \\
\text { High }\end{array}$ & - & + & + & + \\
\hline & $\begin{array}{l}\text { Intermediate- } \\
\text { Low }\end{array}$ & - & \multicolumn{2}{|c|}{ Either one (or none) positive } & + \\
\hline & Low & - & - & - & - \\
\hline \multirow{3}{*}{ AHA } & Massive & + & & & \\
\hline & Submassive & - & \multicolumn{2}{|c|}{ Either one positive } & \\
\hline & Low & - & - & - & \\
\hline
\end{tabular}

Abbreviations: ESC - European Society of Cardiology, AHA - American Heart Association 
(CTEPH) and eventually right heart failure [22]. Given that all forms of VTE will need some form of anticoagulation, hemorrhagic complications in the forms of gastrointestinal, central nervous system (CNS), genitourinary, pulmonary, and other vascular bleeding are not uncommon [9]. Between 2 and 5\% of patients with VTE could experience major bleeding within 3 months [23].

\section{Neurological Complications of Venous Thromboembolism}

Neurological complications following VTE can be divided into three groups (Fig. 1):

(i) CNS complications:

- Intracranial hemorrhage

- Ischemic stroke

- VTE in CNS tumor

(ii) Atypical presentations of PE

- Syncope

- Seizure

(iii) Peripheral nervous system (PNS) complications

- Peripheral neuropathy

- Neuropathic pain syndromes.

\section{Intracranial Hemorrhage}

Intracranial hemorrhage (ICH) is the most feared and welldescribed complication of VTE linked to the treatment of VTE. Standard therapy for VTE involves the use of anticoagulation and/or thrombolytics depending on severity of presentation and with varying risk of ICH. Intracranial hemorrhage is attributed to significant morbidity and mortality [24], as less than half of patients with ICH survive at 1 year and less than one third survive at 5 years [25]. True incidence is difficult to determine and varies according to anticoagulant or thrombolytic used [26]. Risk factors for overall bleeding include older age, female sex, prior bleeding, peptic ulcer disease, active cancer, hypertension, prior stroke, renal or liver disease, and alcohol abuse [27].

Treatment decisions in VTE involve weighing risks and benefits. Most patients with VTE can be treated as outpatients with direct-oral anticoagulants (DOACs), vitamin $\mathrm{K}$ antagonists (VKAs), or low molecular weight heparin (LMWH) [16]. For proximal leg DVTs or PE in the absence of cancer, the American College of Chest Physicians (ACCP) recommends treatment with DOAC such as dabigatran, rivaroxaban, apixaban, or edoxaban over VKA, such as warfarin [18]. DOACs have been shown to prevent recurrence of symptoms and early death in PE [28]. In clinical practice, they have been readily used for their convenience in dosing and administration and reduced overall bleeding risk [29]. A meta-analysis of 17 RCTs by Wolfe et al. examined comparative risk of ICH between different DOACs and reported risk of ICH as odds ratio compared to control (aspirin, warfarin, and LMWH) [30••]. Reported rates of ICH
Fig. 1 Central illustration showing neurologic complications of VTE

\section{Neurologic Complications of VTE}

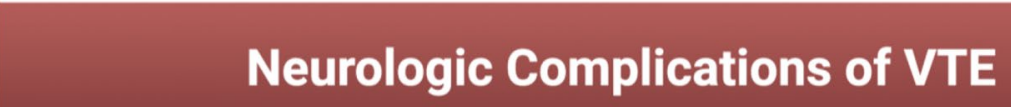

Venous

Thromboembolism

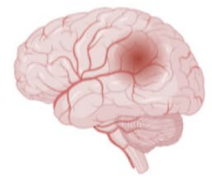

Stroke and Intracranial Hemorrhage

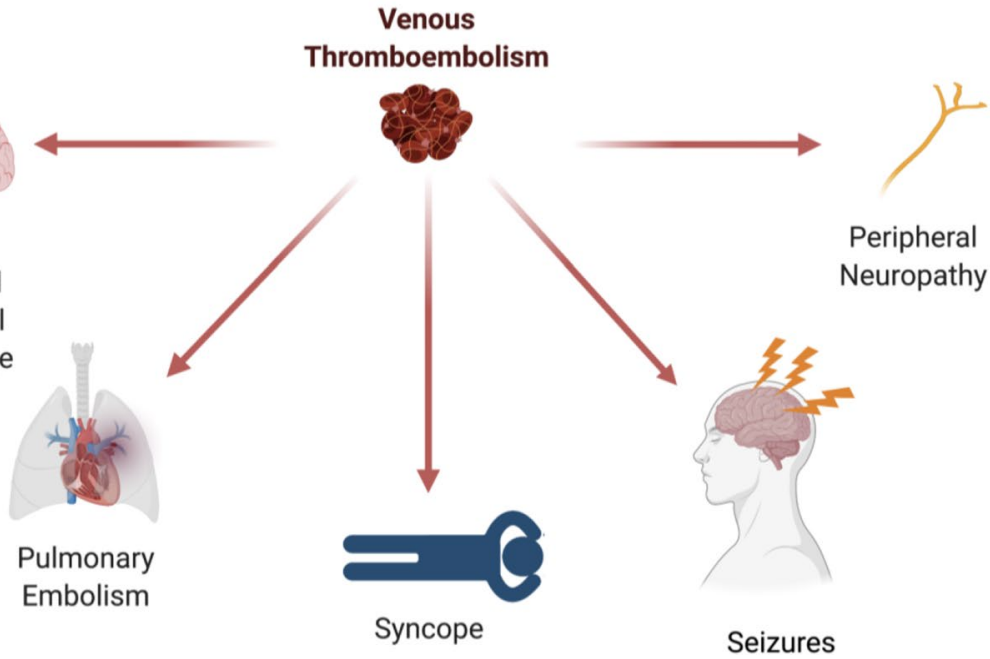


with each anticoagulant from prospective trials are listed in Table 2. Patients with absolute contraindications or failure with anticoagulation may be considered for inferior vena cava (IVC) filter placement, although studies have not shown reduced mortality [31].

The use of thrombolytics is reserved for patients with massive $\mathrm{PE}$ and selected cases of sub massive $\mathrm{PE}$ with higher risk for clinical deterioration. Current ACCP guidelines recommend thrombolytics in patients with acute PE and associated hypotension without high bleeding risk (grade 2B) [18].

Streptokinase, urokinase, and alteplase are currently the only FDA-approved thrombolytics for PE [32]. These agents work by activating plasminogen, causing clot lysis and ultimately improving pulmonary artery pressure and pulmonary perfusion [32]. Thrombolytic therapy has been shown to improve mortality in high-risk population and prevent the development of CTEPH [33-36]. However, improvement in these outcomes comes at the cost of increased risk of ICH (Table 3), with a reported incidence rate of 1-3\% depending on agent used [55]. Absolute contraindications for thrombolytics include structural intracranial disease, previous ICH, ischemic stroke within 3 months, active bleeding, recent brain or spinal surgery, recent head trauma or brain injury, or bleeding diathesis [18]. A meta-analysis of 26 trials including 2784 patients by Izcovich et al. showed an increase in ICH (RR 3.17, 95\% CI 1.19-8.41) with the use of thrombolytics compared to controls [56]. The largest trial evaluating the use of full dose systemic tPA for acute submassive

Table 2 Anticoagulants used for VTE in various studies

\begin{tabular}{|c|c|c|c|}
\hline Drug and dose & Indication/mechanism & Rate of ICH & Study, Year \\
\hline \multirow[t]{2}{*}{ Apixaban $2.5 \mathrm{mg}$} & \multirow[t]{2}{*}{ VTE prophylaxis/Xa inhibitor } & $0 / 3184(0 \%)$ & ADOPT, 2011 \\
\hline & & $0 / 1595(0 \%)$ & ADVANCE, 2009 \\
\hline Apixaban $2.5 \mathrm{mg}$ & $\mathrm{AF} / \mathrm{Xa}$ inhibitor & $0 / 72(0 \%)$ & ARISTOTLE, 2011 \\
\hline \multirow[t]{3}{*}{ Apixaban $5 \mathrm{mg}$} & \multirow[t]{3}{*}{$\mathrm{AF} / \mathrm{Xa}$ inhibitor } & $0 / 71(0 \%)$ & ARISTOTLE, 2011 \\
\hline & & $11 / 2808(0.39 \%)$ & AVERROES, 2011 \\
\hline & & $3 / 2676(0.11 \%)$ & AMPLIFY, 2013 \\
\hline Dabigatran 110 mg & AF/thrombin inhibitor & $27 / 6015(0.44 \%)$ & RE-LY,2009 \\
\hline Dabigatran $150 \mathrm{mg}$ & AF/thrombin inhibitor & $36 / 6076(0.59 \%)$ & RE-LY, 2009 \\
\hline \multirow[t]{3}{*}{ Dabigatran 150 mg } & \multirow[t]{3}{*}{ VTE/thrombin inhibitor } & $0 / 1274(0 \%)$ & RE-COVER I, 2009 \\
\hline & & $2 / 1270(0.16 \%)$ & RE-COVER II, 2014 \\
\hline & & $2 / 1430(0.14 \%)$ & RE-MEDY, 2013 \\
\hline \multirow[t]{2}{*}{ Edoxaban $60 \mathrm{mg}$} & \multirow[t]{2}{*}{ VTE/Xa inhibitor } & $5 / 4118(0.12 \%)$ & Hokusai-VTE, 2013 \\
\hline & & $2 / 522(0.38 \%)$ & Hokusai-VTE Cancer, 2017 \\
\hline Edoxaban $60 \mathrm{mg}$ & $\mathrm{AF} / \mathrm{Xa}$ inhibitor & $61 / 7012(0.87 \%)$ & ENGAGE AF-TIMI 48, 2013 \\
\hline Rivaroxaban $10 \mathrm{mg}$ & VTE prophylaxis/Xa inhibitor & 2/3997 (0.05\%) & MAGELLAN,2013 \\
\hline Rivaroxaban $15 \mathrm{mg}$ & $\mathrm{AF} / \mathrm{Xa}$ inhibitor & $63 / 637(9.89 \%)$ & J ROCKET-AF, 2012 \\
\hline Rivaroxaban $20 \mathrm{mg}$ & $\mathrm{AF} / \mathrm{Xa}$ inhibitor & $55 / 7111(0.77 \%)$ & ROCKET-AF, 2011 \\
\hline Rivaroxaban $20 \mathrm{mg}$ & VTE/Xa inhibitor & $1 / 2412(0.04 \%)$ & EINSTEIN-PE, 2012 \\
\hline \multirow[t]{3}{*}{ LMWH } & \multirow[t]{3}{*}{ VTE prophylaxis/antithrombin activator } & $1 / 1588(0.06 \%)$ & ADVANCE, 2009 \\
\hline & & $2 / 3217(0.06 \%)$ & ADOPT, 2011 \\
\hline & & $0 / 4001(0 \%)$ & MAGELLAN, 2013 \\
\hline LMWH & VTE/antithrombin activator & $4 / 524(0.76 \%)$ & Hokusae-VTE Cancer, 2017 \\
\hline \multirow[t]{6}{*}{ Warfarin } & \multirow[t]{6}{*}{ VTE/vitamin $\mathrm{K}$ antagonist } & $6 / 2689(022 \%)$ & AMPLIFY, 2013 \\
\hline & & $10 / 2405(0.42 \%)$ & EINSTEIN-PE, 2012 \\
\hline & & $18 / 4122(0.44 \%)$ & Hokusaie-VTE, 2012 \\
\hline & & $3 / 1265(0.24 \%)$ & RE-COVER I, 2009 \\
\hline & & $6 / 1289(0.47 \%)$ & RE-COVER II, 2014 \\
\hline & & $4 / 1426(0.28 \%)$ & RE-MEDY, 2013 \\
\hline \multirow[t]{6}{*}{ Warfarin } & \multirow[t]{6}{*}{$\mathrm{AF} /$ vitamin $\mathrm{K}$ antagonist } & $122 / 9052(1.34 \%)$ & ARISTOTLE,2011 \\
\hline & & $13 / 2791(0.47 \%)$ & AVERROES,2011 \\
\hline & & $132 / 7012(1.88 \%)$ & ENGAGE AF-TIMI 48, 2013 \\
\hline & & $87 / 6022(1.44 \%)$ & RE-LY, 2009 \\
\hline & & $84 / 7126(1.1 \%)$ & ROCKET-AF, 2011 \\
\hline & & $76 / 637(11.9 \%)$ & J ROCKET-AF, 2012 \\
\hline
\end{tabular}


Table 3 Thrombolytics and their doses used in various studies

\begin{tabular}{|c|c|c|c|}
\hline Drug and dose & Indication/mechanism & Rate of ICH & Study, Year \\
\hline \multirow[t]{3}{*}{$\mathrm{t}-\mathrm{PA} 0.6 \mathrm{mg} / \mathrm{kg}$} & \multirow[t]{3}{*}{ Thrombolysis/plasminogen activator } & $0 / 33(0 \%)$ & Levine et al., 1990 [37] \\
\hline & & $0 / 60(0 \%)$ & $\begin{array}{l}\text { Goldhaber et al., } 1994 \\
\text { [38] }\end{array}$ \\
\hline & & $0 / 36(0 \%)$ & Sors et al., 1994 [39] \\
\hline $\mathrm{t}-\mathrm{PA} 10-20 \mathrm{mg}$ & Thrombolysis/plasminogen activator & $0 / 30(0 \%)$ & Kucher et al., 2014 [40] \\
\hline $\mathrm{t}-\mathrm{PA} 40-80 \mathrm{mg}$ & Thrombolysis/plasminogen activator & $0 / 9(0 \%)$ & PIOPED, 1990 [41] \\
\hline \multirow[t]{2}{*}{$\mathrm{t}-\mathrm{PA} 50 \mathrm{mg}$} & \multirow[t]{2}{*}{ Thrombolysis/plasminogen activator } & $1 / 55(1.81 \%)$ & Wang et al., 2010 [42] \\
\hline & & $0 / 61(0 \%)$ & Sharifi et al., 2013 [43] \\
\hline \multirow[t]{9}{*}{$\mathrm{t}$-PA $100 \mathrm{mg}$} & \multirow[t]{9}{*}{ Thrombolysis/plasminogen activator } & $0 / 13(0 \%)$ & Tebbe et al., 1999 [44] \\
\hline & & $2 / 44(4.54 \%)$ & $\begin{array}{l}\text { Goldhaber et al., } 1993 \\
\text { [45] }\end{array}$ \\
\hline & & $2 / 27(7.41 \%)$ & $\begin{array}{l}\text { Goldhaber et al., } 1994 \\
\text { [38] }\end{array}$ \\
\hline & & $0 / 34(0 \%)$ & Meyer et al., 1992 [46] \\
\hline & & $0 / 17(0 \%)$ & Sors et al., 1994 [39] \\
\hline & & $0 / 118(0 \%)$ & $\begin{array}{l}\text { Konstantides et al., } 2002 \\
\text { [47] }\end{array}$ \\
\hline & & $0 / 7(0 \%)$ & Muhl et al., 2007 [48] \\
\hline & & $0 / 48(0 \%)$ & Wang et al., 2010 [42] \\
\hline & & $0 / 37(0 \%)$ & Fasullo et al., 2011 [49] \\
\hline r-PA 20 units & Thrombolysis/plasminogen activator & $0 / 23(0 \%)$ & Tebbe et al., 1999 [44] \\
\hline STK 2.65-5.05 million units & Thrombolysis/plasminogen activator & $1 / 75(1.33 \%)$ & Patra et al., 2014 [50] \\
\hline STK 9 million units & Thrombolysis/plasminogen activator & $0 / 8(0 \%)$ & Muhl et al., 2007 [48] \\
\hline Urokinase 57,200 units $/ \mathrm{kg}$ & Thrombolysis/plasminogen activator & $1 / 29(3.44 \%)$ & Meyer et al., 1992 [46] \\
\hline Urokinase 3 million units & Thrombolysis/plasminogen activator & $1 / 45(2.22 \%)$ & $\begin{array}{l}\text { Goldhaber et al., } 1992 \\
\text { [51] }\end{array}$ \\
\hline \multirow[t]{4}{*}{ TNK 30-50 mg } & \multirow[t]{4}{*}{ Thrombolysis/plasminogen activator } & $1 / 28(3.55 \%)$ & Becattini et al., 2010 [52] \\
\hline & & $0 / 25(0 \%)$ & Patra et al., 2014 [50] \\
\hline & & $10 / 506(1.98 \%)$ & Meyer et al., 2014 [53] \\
\hline & & $1 / 40(2.5 \%)$ & Kline et al., 2014 [54] \\
\hline
\end{tabular}

PE was the PEITHO trial - a multicenter, double-blinded study randomizing 1005 patients with submassive PE to either placebo vs weight-based tenecteplase [57]. The trial demonstrated a significant reduction in the primary endpoint of death and hemodynamic collapse $(2.6 \%)$. However, the fibrinolytic treatment was associated with an unacceptable $2.0 \%$ rate of hemorrhage stroke and $6.3 \%$ rate of major extra cranial hemorrhage.

As bleeding complications from thrombolytics are thought to be dose-dependent, various studies investigating optimal dosing have suggested lower doses are equally efficacious with less bleeding risk [58]. Reduced dose thrombolytics are potentially beneficial in high-risk populations such as elderly, pregnant, surgical candidates, and patients weighing less than $65 \mathrm{~kg}$ [59]. A meta-analysis of five trials consisting of 440 patients conducted by Zhang et al. compared low dose rt-PA (50 mg over 2 hours) to standard dose
(100 mg over 2 hours) which showed no statistical difference in recurrent PE or all case mortality with few major bleeding events [32, 60]. Additionally, the MOPPET trial randomized 121 patients with submassive PE to either low dose alteplase $(0.5 \mathrm{mg} / \mathrm{kg}$, max $50 \mathrm{mg})$ or anticoagulation alone and found a reduced incidence of pulmonary hypertension and recurrent $\mathrm{PE}$ in the thrombolytic group with no bleeding events reported in either group [43].

In addition to low-dose thrombolytics, catheter-directed thrombolysis (CDT) has also been studied to reduce hemorrhagic risk in patients with acute PE. The goal of CDT is to locally deliver thrombolytics to the site of thrombus with reduced bleeding risk compared to systemic thrombolytics [61]. The ideal candidate is stable enough to tolerate a prolonged infusion and has a proximal thrombus [40, 62, 63•]. Three prospective trials ULTIMA, SEATTLE II, and PERFECT have shown that CDT can be efficacious with 
relatively low bleeding risk [63•]. The ULTIMA trial randomized 59 patients to CDT plus heparin vs heparin alone and found improvement in RV/LV ratio with no major bleeding in the CDT group [40]. SEATTLE II was a prospective single-arm trial that included 150 patients treated with CDT and found statistical improvement in hemodynamic parameters, with 17 major bleeds but no ICH [62]. The PERFECT registry examined 101 patients with catheter-directed mechanical thrombectomy and/or CDT, with main outcome being composite of hemodynamic parameters and survival to hospital discharge [64]. Their results showed improvement in these measures without major bleeding events, including ICH [64]. While these studies have limitations, they provide evidence that CDT can be safe and efficacious treatment option for acute PE in appropriate patients [63•].

Given the complexity in selecting therapy for VTE patients, multiple bleeding stratification scores have been developed. Scores such as REITE score, outpatient bleeding risk index (OBRI), the Dutch score, and Kuijer scores have all been trialed [65]. The HAS-BLED score, a bleeding stratification tool used for anticoagulation in atrial fibrillation, has also recently been studied in the VTE population and found to have predictive validity. A large retrospective study of 132,280 VTE patients found that patients with scores greater than four were at higher risk for bleeding events [66].

\section{Ischemic Stroke Following VTE}

Compared to hemorrhagic stroke, less is known about subsequent arterial events such as ischemic stroke following VTE. One of the earliest known associations between VTE and atherosclerotic disease is that patients with unprovoked DVTs are more likely to have asymptomatic carotid disease [67]. While the mechanism for this association remains unclear, some contribution is likely due to shared risk factors including obesity, diabetes, and dyslipidemia [68, 69]. Srenson et al. assessed myocardial infarction (MI) and stroke risk in patients with DVT/PE and found the relative risk of ischemic stroke in the first year for PE patients was $2.93(95 \%$ CI 2.34-3.66) and 2.19 (95\% CI 1.85-2.6) for DVT patients, with similar risk with either provoked or unprovoked disease [68]. A 2010 meta-analysis by Becattini et al. that included 17 studies found an increased risk of arterial cardiovascular diseases in patients with unprovoked VTE compared to provoked VTE [52]. Madidrano et al. examined the REITE registry composed of 12,397 PE patients and 10,973 DVT patients for development of subsequent ischemic events while on anticoagulation and found 45 patients with PE suffered ischemic stroke compared to 41 patients with DVT, with subsequent death in 13 and 6 patients, respectively [70].

\section{Patent Foramen Ovale, VTE, and Risk of Stroke}

Patent foramen ovale (PFO) is a persistent fetal communication between the right and left atria due to failure of primum and secundum atrial septa to fuse postpartum. Although the prevalence of PFO is $~ 25 \%$ in the general population, the prevalence increases to nearly $50 \%$ in young patients ( $<55$ years) who present with cryptogenic ischemic stroke [71•]. Under certain hemodynamic conditions with right-to-left atrial shunt (RLS) (e.g., PFO, atrial septal defect (ASD) or atrial septal aneurysm (ASA)) blood and bloodborne products migrate from venous circulation to arterial system leading to paradoxical embolism as reported previously [72-74].

Concomitant PE and acute ischemic stroke is a rare event but has been described in various case reports and series $[75-78,79 \cdot \bullet, 80,81,82 \bullet, 83]$. Treatment of simultaneous PE and acute stroke is challenging due to competing benefits of systemic thrombolytics with risk of hemorrhagic conversion of acute stroke [80, 81]. Lio et al. reviewed 29 concomitant high-risk PE and acute stroke patients (with $90 \%$ prevalence of PFO) who received different modalities of treatment-systemic thrombolysis (40\%), anticoagulation alone (36\%), surgical thrombectomy (16\%), and percutaneous thrombectomy (8\%). Patients receiving systemic thrombolysis and surgical thrombectomy had more favorable outcomes in terms of survival to discharge compared to patients who received anticoagulants alone [79••].

Several prospective and retrospective studies have linked the presence of PFO with increased prevalence of ischemic stroke (clinical or silent) in the patients with acute VTE [82•, 84-86]. Under the physiological conditions, the flap-like PFO defect is passively closed due to left to right pressure gradient. However, this gradient may be reversed during acute PE which results in RLS [87]. In patients with highrisk PE, acute rise in pulmonary hypertension and resultant right heart strain leads to profound and persistent RLS providing a passage for venous thrombi to travel across PFO. In a large prospective study, Le Moigne and colleagues quantified the prevalence of subsequent stroke in 361 consecutive patients presenting with symptomatic PE with and without PFO [72]. The study concluded that presence of PFO was an independent risk factor due to a fourfold increased risk of ischemic stroke. Of note, authors also noticed higher risk of stroke when ASA was present. It is postulated that septal excursions due to ASA allows more flow through PFO leading to increased risk of thrombi migration $[88,89]$. Due to such a high risk of stroke, systematic screening of PFO is essential in this population [90••]. Although TEE 
is considered a gold standard test to diagnose PFO [91], according to 2016 American society of echocardiography guidelines [91], screening with either TTE or TEE with agitated saline contrast has comparable accuracy [92, 93]. However, in either scenario - repeated provocative Valsalva maneuver is crucial to improve accuracy of detecting PFO [94].

Among patients with PE and/or DVT and confirmed PFO, there should be higher suspicion and scrutiny for silent ischemic events, mainly with diffusionweighted brain MRI [95••]. Clergeau et. al [86] studied 60 consecutive patients admitted with PE. All patients underwent clinical neurological assessment followed by diffusion-weighted brain MRI and contrast TTE on the day after admission. PFO was diagnosed in 15/60 (25\%) patients. The frequency of silent brain infarcts was significantly higher in patients with PFO compared to non-PFO (5/15 versus $1 / 45, p=0.003)$ group. At times, the patterns of ischemic brain lesions on diffusionweighted MRI helped to distinguish between PFOstroke compared to other etiology of embolic stroke. In a retrospective qualitative comparison study of 117 PFOstroke patients to 358 patients with atrial fibrillationstroke (AF-stroke), Kim and colleagues [96] showed that a PFO-stroke usually appears as a single cortical or multiple small $(<15 \mathrm{~mm})$ scattered ischemic lesions in the vertebrobasilar circulation without any visible vessel occlusion on angiography.

Cryptogenic stroke (CS) is thought to comprise of $\sim 25 \%$ of all acute ischemic strokes [97]. Although a prospective study showed that PFO is not an independent risk factor for future cerebrovascular events in general population [98], various studies have demonstrated a higher prevalence of $\mathrm{PFO}$ in CS in all age groups despite adjudicating for known risk factors for stroke [99-101]. Ozdemir et al. described that significant history of VTE, migraine, recent prolonged travel, sleep apnea, or a Valsalva maneuver preceding the event are established clinical clues indicating paradoxical embolism among patients with CS [102]. As such, a low threshold should exist to look for VTE in patients with CS linked to PFO when suspicion is high [95••]. However, the absence of DVT on lower extremity ultrasound after CS does not necessarily rule out venous origin of source of embolism as a small clot might have dislodged or dissolved [103]. Mounting evidence suggests that PFO device closure is more effective than medical therapy alone for secondary prevention of suspected embolic stroke of uncertain etiology (ESUS) in select patients aged less than 60 years with large PFO with or without associated ASA [104-106]. According to a 2018 meta-analysis of 4 high-quality RCTs enrolling 2531 patients [107•], PFO closure led to $60 \%$ reduction in recurrent ischemic strokes over 3-6 years follow-up period.
Miscellaneous Conditions and Risk of Stroke

\section{May-Thurner Syndrome and Risk of Stroke}

May-Thurner syndrome (MTS) (also known as iliac vein compression syndrome or Cockett's syndrome) is a rare anatomical variant where right iliac artery compresses left iliac vein against the lumbar spine leading to increased risk of left leg DVT [108, 109•]. In a retrospective study of 470 CS patients undergoing PFO closure at a single center, Kiernan et al. found 30/470 (6.3\%) patients had MTS on MR venography of pelvis. While majority of them were women (80\%), 40\% had thrombophilia and 54\% women were taking birth-control pills [110]. In another retrospective study of 214 patients with CS comparing 50 controls, not only prevalence of MTS and PFO was significant higher in CS patients ( $p=0.0001, p=0.0023$, respectively), but compression of left iliac vein was also significantly greater (32\% vs $13 \%, p<0.00001)$ [111].

\section{COVID-19 Infection and Risk of VTE and Stroke}

Severe acute respiratory syndrome coronavirus (SARsCoV-2) has resulted in a global pandemic of COVID-19, with more than 130 million cases and 2.8 million deaths by the end of March 2021 [112]. Although predominantly known as a respiratory illness, its inflammatory response predisposes to thrombotic complications such as MI, VTE, and ischemic stroke [113]. The risk of VTE in patients with COVID-19 admitted to the ICU has been estimated between 20 and 40\% [114]. Additionally, a systematic review of 55,176 COVID-19 patients reported an average incidence of stroke as $1.74 \%$ (95\% CI: 1.09-2.51\%), with an average stroke mortality of $31.76 \%$ (95\% CI: 17.77-47.31\%) [115•]. Proposed mechanisms for ischemic strokes in this population includes systemic inflammatory response, comorbid cardiovascular conditions, as well as direct invasion of the brain parenchyma by SARS-COV-2 [115•, 116].

\section{VTE and Risk of Malignancies}

Cancer is a known risk factor for VTE with a sevenfold increase incidence of VTE associated with malignancy [117]. The underlying mechanism for this involves a complex array of molecular interactions driven by the expression of hemostatic proteins, adhesion molecules, inflammatory cytokines, proangiogenic factors, microparticles by tumor and host cells, and even vascular compression from tumor burden [118, 119]. Thrombotic sequelae of cancer can also manifest in other ways, including a nearly twofold 
increase in ischemic stroke incidence [120], as well as disseminated intravascular coagulation (DIC) and Trousseau syndrome (TS). TS is the manifestation of migratory thrombophlebitis in the setting of malignancy. Though the exact mechanism remains unclear, it is often seen in mucin-producing cancers such as gastric cancer. Embolic stroke diagnosed in malignancy, especially when occurring in disparate cerebral regions, should raise suspicion for TS [121•, 122-124]. Cerebral infarction from TS has been documented across a wide spectrum of malignancies from benign adenomyosis to thyroid cancer $[121 \bullet, 125]$.

One-year cumulative incidence of VTE following malignancy is varied after solid tumors - brain (6.9\%), pancreas $(5.3 \%)$, stomach $(4.5 \%)$, and lung (2.4\%)—and hematological malignancies, acute myelogenous leukemia (3.7\%) and chronic myelogenous leukemia (1.5\%) [120, 126]. Patients with metastases have a higher risk compared to those without (OR 19.8) [117]. Depending on the type of CNS malignancy, annual VTE incidence ranges from 0.5 to $20 \%$ [127]. Glioblastoma is the CNS tumor with highest incidence of VTE (15.7\%), while meningioma rarely leads to VTE $(<1 \%)$ [128]. Other tumor-related risk factors leading to increased risk of VTE include larger size, intraluminal thrombosis, IDH1 wild-type, high soluble $\mathrm{P}$ selectin levels, and podoplanin expression [129••, $130,131]$, as well as subtotal surgical resection, use of corticosteroids, anti-VEGF therapy, leukocytosis, and thrombocytopenia [128, 132, 133]. Notably, patients with malignant gliomas who develop VTE within the first 2 years have a $30 \%$ higher risk of death [134].

\section{Atypical Presentations of Pulmonary Embolism}

\section{Syncope and Pulmonary Embolism}

Syncope is not a classical presentation of PE, but not an uncommon one with an estimated incidence of $13 \%$ in all patients with PE [135]. It can be explained by three possible mechanisms [135]. (1) Occlusion of the pulmonary vascular tree causing right ventricular failure and impaired left ventricular filling, leading to a reduction in cardiac output, arterial hypotension, cerebral hypoperfusion, and, ultimately, loss of consciousness. (2) Right ventricular overload and dilatation predisposing to a variety of arrhythmias, including ventricular tachycardia or ventricular fibrillation. In patients with pre-existing conduction system disease, the development of a right bundle branch block commonly seen in acute pulmonary embolism can cause complete AV block and other brady-dysrhythmias.
(3) Finally, PE may trigger a neurogenic syncope via a vasovagal reflex. The Bezold-Jarisch reflex of bradycardia and coronary vasodilation can lead to profound systemic hypotension, cerebral hypoperfusion, and syncope in acute $\mathrm{RV}$ ischemia[136, 137]

Among all presentations of PE, syncope portends a worse prognosis [138-145], though some contradictory studies show no difference in mortality [135, 145-147]. In the International Cooperative Pulmonary Embolism Registry, the 3-month mortality rate of patients with syncope was $26.8 \%$ compared to $17 \%$ in the non-syncope PE population [148]. Syncope was associated with a higher prevalence of hemodynamic instability (OR 3.5), echocardiographic signs of RV dysfunction (OR 2.1), 30-day all-cause mortality (OR 1.73), and PE-related 30-day adverse outcomes (OR 2.0) [149••]. Conversely, in patients with syncope, prevalence of PE is around $8-17 \%$ [67, 135, 146, 150-152]. In most studies, syncope led to a diagnosis of acute PE in the setting of other symptoms like chest pain, dyspnea, tachycardia, or tachypnea [153]. Certain factors which have been shown to predict syncope in PE patients are larger clot burden [154, 155], central location of PE [147, 156], and saddle embolism [147].

\section{Seizures and Pulmonary Embolism}

PE can present heterogeneously, with seizures being one of the rarest and most interesting clinical manifestations. Mostly described in the literature as case reports [157-160], acute PE presenting with new onset seizures is believed to occur in less than $1 \%$ of PE cases [157]. Potential pathophysiology includes hypoxia-driven cardiogenic seizures, with right ventricular failure and decreased cardiac output leading to transient global cerebral hypoperfusion [158]. A literature review by Zuin et al. [161••] identified 16 case reports where focal and generalized seizures were identified in $37.5 \%$ and $50 \%$ of PE cases, respectively, with the remainder lacking sufficient data for diagnosis. Neurologic comorbidities such as history of childhood epilepsy, stroke, and syncope were identified in $25 \%$ of the patients. Eleven of the 16 patients were hemodynamically stable on admission, with systemic thrombolysis eventually being used in 5 cases. The reported morality rate was $54.5 \%$, with diagnosis of PE retrospectively made at autopsy in $25 \%$ of patients. The high mortality rate is largely attributed to delay in diagnosis, a challenge also described in previous case reports [160, 162, 163]. Clinicians have the difficult task of recognizing underlying PE in the presentation of seizure while also ruling out concomitant ICH prior to starting treatment [161••]. Further investigation needs to be aimed at identifying the predisposing risk factors, clinical presentation, and treatment for these challenging cases. 


\section{Peripheral Nervous System Complications of VTE}

VTE, and the treatment of VTE, can affect the PNS in a number of ways. The most common mechanism of peripheral nerve injury in connection with VTE is a post-thrombotic syndrome (PTS). Up to half of all patients with acute proximal DVT will develop PTS, and 5-10\% will develop severe symptoms [164]. The mechanism of neuropathic pain associated with PTS appears to be a combination of both inflammation surrounding affected nerves and possibly a demyelinating process [165]. While the treatment of PTS is centered on symptomatic management of the neuropathic pain, prevention relies on the use of elastic compression stockings to reduce venous hypertension and exercise [164].

In addition to PTS, peripheral neuropathy from VTE can occur, although rarely, due to direct entrapment neuropathy from DVT or due to VTE treatment. Femoral neuropathy can develop as a consequence of VTE through retroperitoneal hematoma from anticoagulation [166]. Moreover, direct damage to the femoral nerve via transfemoral approaches in CDT or mechanical thrombectomy is possible with an incidence of $1.5 \%$ [167]. VTE of the crural veins causing entrapment neuropathy has been described in case reports of peroneal neuropathy resulting in foot drop $[168,169]$. In the upper extremity, brachial vein DVT has been reported as a cause of cubital tunnel syndrome.[170]. Median nerve entrapment neuropathy secondary to spontaneous hemorrhage into the carpal tunnel following anticoagulation for VTE has also been reported [171].

\section{Conclusions}

VTE is known to have heterogeneous presentations leading to morbid or fatal outcomes. While cardiovascular complications of DVT/PE are well-known, neurologic consequences of VTE are mainly known for ICH which is indirectly linked to the treatment of VTE. In addition to ICH, this review has described the other potential yet underdiagnosed complications of VTE such as acute ischemic strokes, risk of CS in the setting of right-to-left intracardiac shunts, and some of the peripheral entrapment neuropathies due to DVT and post-thrombotic syndrome. The association between VTE and neurologic complications is complex, and further investigation is needed to guide management.

Funding No specific funding was associated with this research

\section{Declarations}

Disclosures None relevant to the present work

\section{References}

Papers of particular interest, published recently, have been highlighted as:

- Of importance

- Of major importance

1. Wendelboe AM, Raskob GE. Global burden of thrombosis: Epidemiologic aspects. Circ Res. 2016;118:1340-7. Available from: https://doi.org/10.1161/CIRCRESAHA.115.306841.

2. Beckman MG, Hooper WC, Critchley SE, Ortel TL. Venous thromboembolism: a public health concern. Am J Prev Med. 2010;38:S495-501. Available from: https://doi.org/10.1016/j. amepre.2009.12.017.

3. Grosse SD, Nelson RE, Nyarko KA, Richardson LC, Raskob GE. The economic burden of incident venous thromboembolism in the United States: A review of estimated attributable healthcare costs. Thromb Res. 2016;137:3-10. Available from: https://doi. org/10.1016/j.thromres.2015.11.033.

4. Bagot CN, Arya R. Virchow and his triad: a question of attribution. Br J Haematol. 2008;143:180-90. Available from: https:// doi.org/10.1111/j.1365-2141.2008.07323.x.

5. Rinde LB, Småbrekke B, Mathiesen EB, Løchen M-L, Njølstad I, Hald EM, et al. Ischemic Stroke and Risk of Venous Thromboembolism in the General Population: The Troms $\varnothing$ Study. J Am Heart Assoc. 2016;5. Available from: https://doi.org/10.1161/ JAHA.116.004311.

6. Kucher N. Clinical practice. Deep-vein thrombosis of the upper extremities. N Engl J Med. 2011;364:861-9. Available from: https://doi.org/10.1056/NEJMcp1008740.

7. Kearon C, Ageno W, Cannegieter SC, Cosmi B, Geersing G-J, Kyrle PA, et al. Categorization of patients as having provoked or unprovoked venous thromboembolism: guidance from the SSC of ISTH. J Thromb Haemost. 2016;14:1480-3. Available from: https://doi.org/10.1111/jth.13336.

8. Moheimani F, Jackson DE. Venous thromboembolism: classification, risk factors, diagnosis, and management. ISRN Hematol. 2011;2011:124610. Available from: https://doi.org/10.5402/2011/ 124610.

9. Levine MN, Raskob G, Beyth RJ, Kearon C, Schulman S. Hemorrhagic complications of anticoagulant treatment: the Seventh ACCP Conference on Antithrombotic and Thrombolytic Therapy. Chest. 2004;126:287S-310S. Available from: https://doi. org/10.1378/chest.126.3_suppl.287S.

10. Ho WK. Deep vein thrombosis--risks and diagnosis. Aust Fam Physician. 2010;39:468-74. Available from: https://www.ncbi. nlm.nih.gov/pubmed/20628659.

11. Scarvelis D, Wells PS. Diagnosis and treatment of deep-vein thrombosis. CMAJ. 2006;175:1087-92. Available from: https://doi.org/10.1503/cmaj.060366.

12. Kearon C. Natural history of venous thromboembolism. Circulation. 2003;107:I22-30. Available from: https://doi.org/10. 1161/01.CIR.0000078464.82671.78.

13. Snow V, Qaseem A, Barry P, Hornbake ER, Rodnick JE, Tobolic T, et al. Management of venous thromboembolism: a clinical practice guideline from the American College of Physicians and the American Academy of Family Physicians. Ann Intern Med. 2007;146:204-10. Available from: https:// doi.org/10.7326/0003-4819-146-3-200702060-00149.

14. Kahn SR. The post thrombotic syndrome. Thromb Res. 2011;127 Suppl 3:S89-92. Available from: https://doi.org/ 10.1016/S0049-3848(11)70024-X.

15. Winter M-P, Schernthaner GH, Lang IM. Chronic complications of venous thromboembolism. J Thromb Haemost. 
2017;15:1531-40. Available from: https://doi.org/10.1111/ jth.13741.

16. Wilbur J, Shian B. Deep venous thrombosis and pulmonary embolism: Current therapy. Am Fam Physician. 2017;95:295302. Available from: https://www.ncbi.nlm.nih.gov/pubmed/ 28290648.

17. Jaff MR, McMurtry MS, Archer SL, Cushman M, Goldenberg $\mathrm{N}$, Goldhaber SZ, et al. Management of massive and submassive pulmonary embolism, iliofemoral deep vein thrombosis, and chronic thromboembolic pulmonary hypertension: A scientific statement from the american heart association. Circulation. 2011. Available from: https://doi.org/10.1161/CIR.0b013 e318214914f.

18. Kearon C, Akl EA, Ornelas J, Blaivas A, Jimenez D, Bounameaux $\mathrm{H}$, et al. Antithrombotic therapy for VTE disease: CHEST guideline and expert panel report. Chest. 2016. Available from: https://doi.org/10.1016/j.chest.2015.11.026.

19. Becattini C, Agnelli G. Risk stratification and management of acute pulmonary embolism. Hematology Am Soc Hematol Educ Program. 2016;2016:404-12. Available from: https://doi. org/10.1182/asheducation-2016.1.404.

20. Aujesky D, Obrosky DS, Stone RA, Auble TE, Perrier A, Cornuz J, et al. Derivation and validation of a prognostic model for pulmonary embolism. Am J Respir Crit Care Med. 2005;172:1041-6. Available from: https://doi.org/10.1164/ rccm.200506-8620C

21. Jiménez D, Aujesky D, Moores L, Gómez V, Lobo JL, Uresandi F, et al. Simplification of the pulmonary embolism severity index for prognostication in patients with acute symptomatic pulmonary embolism. Arch Intern Med. 2010;170:1383-9. Available from: https://doi.org/10.1001/ archinternmed.2010.199.

22. Fanikos J, Piazza G, Zayaruzny M, Goldhaber SZ. Long-term complications of medical patients with hospital-acquired venous thromboembolism. Thromb Haemost. 2009;102:688-93. Available from: https://doi.org/10.1160/TH09-04-0266.

23. Nieto JA, Camara T, Gonzalez-Higueras E, Ruiz-Gimenez N, Guijarro R, Marchena PJ, et al. Clinical outcome of patients with major bleeding after venous thromboembolism. Findings from the RIETE Registry. Thromb Haemost. 2008;100:789-96. Available from: https://www.ncbi.nlm.nih.gov/pubmed/18989 522.

24. Hart RG, Diener HC, Yang S, Connolly SJ, Wallentin L, Reilly $\mathrm{PA}$, et al. Intracranial hemorrhage in atrial fibrillation patients during anticoagulation with warfarin or dabigatran: The RE-LY trial. Stroke. 2012. Available from: https://doi.org/10.1161/ STROKEAHA.112.650614.

25. Poon MTC, Fonville AF, Salman RAS. Long-term prognosis after intracerebral haemorrhage: Systematic review and metaanalysis. J Neurol Neurosurg Psychiatry. 2014. Available from: https://doi.org/10.1136/jnnp-2013-306476.

26. Daley MJ, Murthy MS, Peterson EJ. Bleeding risk with systemic thrombolytic therapy for pulmonary embolism: Scope of the problem. Ther Adv Drug Saf. 2015. Available from: https:// doi.org/10.1177/2042098615572333.

27. Klok FA, Kooiman J, Huisman MV, Konstantinides S, Lankeit M. Predicting anticoagulant-related bleeding in patients with venous thromboembolism: A clinically oriented review. Eur Respir J. 2015. Available from: https://doi.org/10.1183/09031 936.00040714

28. Konstantinides SV, Torbicki A, Agnelli G, Danchin N, Fitzmaurice D, Galiè N, et al. 2014 ESC Guidelines on the diagnosis and management of acute pulmonary embolism. Eur Heart J. 2014. Available from: https://doi.org/10.1093/eurhe artj/ehu283.
29. Di Nisio M, van Es N, Büller HR. Deep vein thrombosis and pulmonary embolism. Lancet. 2016. Available from: https://doi. org/10.1016/S0140-6736(16)30514-1.

30.• Wolfe Z, Khan SU, Nasir F, Raghu Subramanian C, Lash B. A systematic review and Bayesian network meta-analysis of risk of intracranial hemorrhage with direct oral anticoagulants. J Thromb Haemost. 2018. Available from: https://doi.org/10.1111/ jth.14131. A meta-analysis comparing risk of ICH between various newer anticoagulants.

31. Mismetti P, Laporte S, Pellerin O, Ennezat P-V, Couturaud F, Elias A, et al. PREPIC 2 (2015; JAMA) IVC filters for high-risk PE. JAMA. 2015.

32. Martin C, Sobolewski K, Bridgeman P, Boutsikaris D. Systemic thrombolysis for pulmonary embolism: A review. P T. 2016;41:770-5. Available from: https://www.ncbi.nlm.nih.gov/ pubmed/27990080.

33. Vedantham S, Piazza G, Sista AK, Goldenberg NA. Guidance for the use of thrombolytic therapy for the treatment of venous thromboembolism. J Thromb Thrombolysis. 2016. Available from: https://doi.org/10.1007/s11239-015-1318-z.

34. Chatterjee S, Chakraborty A, Weinberg I, Kadakia M, Wilensky RL, Sardar P, et al. Thrombolysis for pulmonary embolism and risk of all-cause mortality, major bleeding, and intracranial hemorrhage: A meta-analysis. JAMA. 2014. Available from: https:// doi.org/10.1001/jama.2014.5990.

35. Kline JA, Steuerwald MT, Marchick MR, Hernandez-Nino J, Rose GA. Prospective evaluation of right ventricular function and functional status 6 months after acute submassive pulmonary embolism: Frequency of persistent or subsequent elevation in estimated pulmonary artery pressure. Chest. 2009; Available from: $10.1378 /$ chest.08-2988

36. Jerjes-Sanchez C, Ramírez-Rivera A, de Lourdes García M, Arriaga-Nava R, Valencia S, Rosado-Buzzo A, et al. Streptokinase and heparin versus heparin alone in massive pulmonary embolism: A randomized controlled trial. J Thromb Thrombolysis. 1995. Available from: https://doi.org/10.1007/BF01062714.

37. Levine M, Hirsh J, Weitz J, Cruickshank M, Neemeh J, Turpie AG, et al. A randomized trial of a single bolus dosage regimen of recombinant tissue plasminogen activator in patients with acute pulmonary embolism. Chest. 1990;98:1473-9. Available from: https://doi.org/10.1378/chest.98.6.1473.

38. Goldhaber SZ, Agnelli G, Levine MN. Reduced dose bolus alteplase vs conventional alteplase infusion for pulmonary embolism thrombolysis. An international multicenter randomized trial. The Bolus Alteplase Pulmonary Embolism Group. Chest. 1994;106:718-24. Available from: https://doi. org/10.1378/chest.106.3.718.

39. Sors H, Pacouret G, Azarian R, Meyer G, Charbonnier B, Simonneau G. Hemodynamic effects of bolus vs 2-h infusion of alteplase in acute massive pulmonary embolism. A randomized controlled multicenter trial. Chest. 1994;106:712-7. Available from: https://doi.org/10.1378/chest.106.3.712.

40. Kucher N, Boekstegers P, Müller OJ, Kupatt C, Beyer-Westendorf J, Heitzer T, et al. Randomized, controlled trial of ultrasoundassisted catheter-directed thrombolysis for acute intermediate-risk pulmonary embolism. Circulation. 2014. Available from: https:// doi.org/10.1161/CIRCULATIONAHA.113.005544.

41. PIOPED Investigators. Value of the ventilation/perfusion scan in acute pulmonary embolism. Results of the prospective investigation of pulmonary embolism diagnosis (PIOPED). JAMA. 1990;263:2753-9. Available from: https://doi.org/10. 1001/jama.1990.03440200057023.

42. Wang C, Zhai Z, Yang Y, Wu Q, Cheng Z, Liang L, et al. Efficacy and safety of low dose recombinant tissue-type plasminogen activator for the treatment of acute pulmonary 
thromboembolism: a randomized, multicenter, controlled trial. Chest. 2010;137:254-62. Available from: https://doi.org/10. 1378/chest.09-0765.

43. Sharifi M, Bay C, Skrocki L, Rahimi F, Mehdipour M. Moderate pulmonary embolism treated with thrombolysis (from the "mOPETT" Trial). Am J Cardiol. 2013. Available from: https:// doi.org/10.1016/j.amjcard.2012.09.027.

44. Tebbe U, Graf A, Kamke W, Zahn R, Forycki F, Kratzsch G, et al. Hemodynamic effects of double bolus reteplase versus alteplase infusion in massive pulmonary embolism. Am Heart J. 1999;138:39-44. Available from: https://doi.org/10.1016/ s0002-8703(99)70243-7.

45. Goldhaber SZ, Haire WD, Feldstein ML, Miller M, Toltzis R, Smith JL, et al. Alteplase versus heparin in acute pulmonary embolism: randomised trial assessing right-ventricular function and pulmonary perfusion. Lancet. 1993;341:507-11. Available from: https://doi.org/10.1016/0140-6736(93)90274-k.

46. Meyer G, Sors H, Charbonnier B, Kasper W, Bassand JP, Kerr $\mathrm{IH}$, et al. Effects of intravenous urokinase versus alteplase on total pulmonary resistance in acute massive pulmonary embolism: a European multicenter double-blind trial. The European Cooperative Study Group for Pulmonary Embolism. J Am Coll Cardiol. 1992;19:239-45. Available from: https://doi.org/10. 1016/0735-1097(92)90472-y.

47. Konstantinides S, Geibel A, Heusel G, Heinrich F, Kasper W, Management Strategies and Prognosis of Pulmonary Embolism-3 Trial Investigators. Heparin plus alteplase compared with heparin alone in patients with submassive pulmonary embolism. N Engl J Med. 2002;347:1143-50. Available from: https://doi. org/10.1056/NEJMoa021274.

48. Mühl D, Füredi R, Gecse K, Ghosh S, Falusi B, Bogár L, et al. Time course of platelet aggregation during thrombolytic treatment of massive pulmonary embolism. Blood Coagul Fibrinolysis. 2007;18:661-7. Available from: https://doi.org/10.1097/ MBC.0b013e3282e38e61.

49. Fasullo S, Scalzo S, Maringhini G, Ganci F, Cannizzaro S, Basile I, et al. Six-month echocardiographic study in patients with submassive pulmonary embolism and right ventricle dysfunction: comparison of thrombolysis with heparin. Am J Med Sci. 2011;341:33-9. Available from: https://doi.org/10.1097/MAJ. 0b013e3181f1fc3e.

50. Patra S, Agrawal N, Manjunath CN, Nagesh CM, Srinivas BC, Ravindranath KS, et al. Thrombolytic therapy in the treatment of acute sub-massive pulmonary embolism: a prospective observational study. Blood Coagul Fibrinolysis. 2014;25:167-71. Available from: https://doi.org/10.1097/MBC.0000000000000015.

51. Goldhaber SZ, Kessler CM, Heit JA, Elliott CG, Friedenberg WR, Heiselman DE, et al. Recombinant tissue-type plasminogen activator versus a novel dosing regimen of urokinase in acute pulmonary embolism: a randomized controlled multicenter trial. J Am Coll Cardiol. 1992;20:24-30. Available from: https://doi. org/10.1016/0735-1097(92)90132-7.

52. Becattini C, Vedovati MC, Ageno W, Dentali F, Agnelli G. Incidence of arterial cardiovascular events after venous thromboembolism: A systematic review and a meta-analysis. J Thromb Haemost. 2010. Available from: https://doi.org/10.1111/j.15387836.2010.03777.x.

53. Meyer G, Vicaut E, Danays T, Agnelli G, Becattini C, BeyerWestendorf J, et al. Fibrinolysis for patients with intermediaterisk pulmonary embolism. N Engl J Med. 2014;370:1402-11. Available from: https://doi.org/10.1056/NEJMoa1302097.

54. Kline JA, Nordenholz KE, Courtney DM, Kabrhel C, Jones AE, Rondina MT, et al. Treatment of submassive pulmonary embolism with tenecteplase or placebo: cardiopulmonary outcomes at 3 months: multicenter double-blind, placebo-controlled randomized trial. J Thromb Haemost. 2014;12:459-68. Available from: https://doi.org/10.1111/jth.12521.

55. Stein PD, Matta F, Keyes DC, Willyerd GL. Impact of Vena Cava Filters on in-Hospital case fatality rate from pulmonary embolism. Am J Med. 2012. Available from: https://doi.org/10. 1016/j.amjmed.2011.05.025.

56. Izcovich A, Criniti JM, Popoff F, Lu L, Wu J, Ageno W, et al. Thrombolytics for venous thromboembolic events: A systematic review with meta-analysis. Blood Adv. 2020. Available from: https://doi.org/10.1182/bloodadvances.2020001513.

57. Meyer G, Vicaut E, Danays T, Agnelli G, Becattini C, BeyerWestendorf J, et al. Fibrinolysis for Patients with IntermediateRisk Pulmonary Embolism. N Engl J Med. 2014. Available from: https://doi.org/10.1056/nejmoa1302097.

58. Wan S, Quinlan DJ, Agnelli G, Eikelboom JW. Thrombolysis compared with heparin for the initial treatment of pulmonary embolism: A meta-analysis of the randomized controlled trials. Circulation. 2004. Available from: https://doi.org/10.1161/01. CIR.0000137826.09715.9C.

59. Brandt K, McGinn K, Quedado J. Low-Dose Systemic Alteplase (tPA) for the Treatment of Pulmonary Embolism. Ann Pharmacother. 2015. Available from: https://doi.org/10.1177/10600 28015579988.

60. Zhang Z, Zhai ZG, Liang LR, Liu FF, Yang YH, Wang C. Lower dosage of recombinant tissue-type plasminogen activator (rt-PA) in the treatment of acute pulmonary embolism: A systematic review and meta-analysis. Thromb Res. 2014. Available from: https://doi.org/10.1016/j.thromres.2013.12.026.

61. Dudzinski DM, Giri J, Rosenfield K. Interventional Treatment of Pulmonary Embolism. Circ Cardiovasc Interv. 2017. Available from: https://doi.org/10.1161/CIRCINTERVENTIONS.116. 004345.

62. Piazza G, Hohlfelder B, Jaff MR, Ouriel K, Engelhardt TC, Sterling KM, et al. A Prospective, Single-Arm, Multicenter Trial of Ultrasound-Facilitated, Catheter-Directed, Low-Dose Fibrinolysis for Acute Massive and Submassive Pulmonary Embolism: The SEATTLE II Study. JACC Cardiovasc Interv. 2015. Available from: https://doi.org/10.1016/j.jcin.2015.04.020.

63. Chiarello MA, Sista AK. Catheter-Directed Thrombolysis for Submassive Pulmonary Embolism. Semin Intervent Radiol. 2018. Available from: https://doi.org/10.1055/s-0038-1642041. This review describes clinical presentation of submissive PE and role for catheter directed thrombolysis.

64. Kuo WT, Banerjee A, Kim PS, De Marco FJ, Levy JR, Facchini FR, et al. Pulmonary embolism response to fragmentation, embolectomy, and catheter thrombolysis (PERFECT): Initial results from a prospective multicenter registry. Chest. 2015. Available from: https://doi.org/10.1378/chest.15-0119.

65. Scherz N, Méan M, Limacher A, Righini M, Jaeger K, Beer HJ, et al. Prospective, multicenter validation of prediction scores for major bleeding in elderly patients with venous thromboembolism. J Thromb Haemost. 2013. Available from: https://doi.org/ 10.1111/jth.12111.

66. Brown JD, Goodin AJ, Lip GYH, Adams VR. Risk stratification for bleeding complications in patients with venous thromboembolism: Application of the HAS-BLED bleeding score during the first 6 months of anticoagulant treatment. J Am Heart Assoc. 2018; Available from: https://doi.org/10.1161/JAHA.117. 007901.

67. Prandoni P, Bilora F, Marchiori A, Bernardi E, Petrobelli F, Lensing AWA, et al. An Association between Atherosclerosis and Venous Thrombosis. N Engl J Med. 2003. Available from: https://doi.org/10.1056/nejmoa022157.

68. Srensen HT, Horvath-Puho E, Pedersen L, Baron JA, Prandoni P. Venous thromboembolism and subsequent hospitalisation due 
to acute arterial cardiovascular events: a 20-year cohort study. Lancet. 2007. Available from: https://doi.org/10.1016/S01406736(07)61745-0.

69. Ageno W, Becattini C, Brighton T, Selby R, Kamphuisen PW. Cardiovascular risk factors and venous thromboembolism: A meta-analysis. Circulation. 2008. Available from: https://doi.org/ 10.1161/CIRCULATIONAHA.107.709204.

70. Madridano O, Del Toro J, Lorenzo A, Martín M, Gómez Cerezo J, Hernández L, et al. Subsequent arterial ischemic events in patients receiving anticoagulant therapy for venous thromboembolism. J Vasc Surg: Venous Lymphat Disord. 2015. Available from: https://doi.org/10.1016/j.jvsv.2014.11.002.

71. Koutroulou I, Tsivgoulis G, Tsalikakis D, Karacostas D, Grigoriadis N, Karapanayiotides T. Epidemiology of patent foramen ovale in general population and in stroke patients: A narrative review. Front Neurol. 2020;11:281. Available from: https://doi. org/10.3389/fneur.2020.00281. This review described the prevalence of $\mathrm{PFO}$ in general population and stroke patients and emphasized that it should not be underestimated.

72. Greenberg JW, Goff ZD, Mooser AC, Wittgen CM, Smeds MR. Acute Limb Ischemia Secondary to Patent Foramen OvaleMediated Paradoxical Embolism: A Case Report and Systematic Review of the Literature. Ann Vasc Surg. 2020;66:668.e5-668. e10. Available from: https://doi.org/10.1016/j.avsg.2019.12.022.

73. Zafar H, Anderson L, Cox AT, Bastiaenen R. Pulmonary embolism and infarction with a paradoxical thrombus visualised in both atria. BMJ Case Rep. 2018;2018. Available from: https:// doi.org/10.1136/bcr-2018-225195.

74. Nuñez R, Sanchez JA, Berber S, Loaiza F, Nuñez JG, Arias S, et al. Case report: Thrombus in transit-a cause of impending paradoxical embolism. Eur Heart J - Case Rep. Oxford Academic; 2021 [cited 2021 Mar 28];5. Available from: https:// academic.oup.com/ehjcr/article/5/2/ytaa580/6138215.

75. Allport LE, Butcher KS. Thrombolysis for concomitant acute stroke and pulmonary embolism. J Clin Neurosci. 2008;15:91720. Available from: https://doi.org/10.1016/j.jocn.2007.03.026.

76. Barros-Gomes S, El Sabbagh A, Eleid MF, Mankrad SV. Concomitant acute stroke, pulmonary and myocardial infarction due to in-transient thrombus across a patent foramen ovale. Echo Res Pract. 2018;5:I9-10. Available from: https://doi.org/10.1530/ ERP-18-0044.

77. Lak HM, Ahmed T, Nair R, Maroo A. Simultaneous multifocal paradoxical embolism in an elderly patient with patent foramen ovale: A case report. Cureus. 2020;12:e6992. Available from: https://doi.org/10.7759/cureus.6992.

78. Lapostolle F, Borron SW, Surget V, Sordelet D, Lapandry C, Adnet F. Stroke associated with pulmonary embolism after air travel. Neurology. 2003;60:1983-5. Available from: https://doi. org/10.1212/01.wnl.0000068025.97902.28.

79.• Lio KU, Jiménez D, Moores L, Rali P. Clinical conundrum: concomitant high-risk pulmonary embolism and acute ischemic stroke. Emerg Radiol. 2020;27:433-9. Available from: https:// doi.org/10.1007/s10140-020-01772-7. A descriptive literature review of presentation, treatment and prognosis of high-risk $P E$ and acute ischemic stroke.

80. Naidoo P, Hift R. Massive pulmonary thromboembolism and stroke. Case Rep Med. 2011;2011:398571. Available from: https://doi.org/10.1155/2011/398571.

81. Pavesi PC, Pedone C, Crisci M, Piacentini A, Fulvi M, Di Pasquale G. Concomitant submassive pulmonary embolism and paradoxical embolic stroke after a long flight: which is the optimal treatment? J Cardiovasc Med. 2008;9:1070-3. Available from: https://doi.org/10.2459/JCM.0b013e328306f2ea.

82. Vindiš D, Hutyra M, Šaňák D, Král M, Čecháková E, Littnerová S, et al. Patent Foramen Ovale and the Risk of Cerebral Infarcts in Acute Pulmonary Embolism-A Prospective Observational
Study. J Stroke Cerebrovasc Dis. 2018;27:357-64. Available from: https://doi.org/10.1016/j.jstrokecerebrovasdis.2017.09. 004. This observational study describes the prevalence of PFO and risk of stroke in patients with PE.

83. Zhang H-Y, Zhang Y, Cao Y-J, Mei L-L, Zhang X, Wu Z-G, et al. Acute inferior ST-segment elevation myocardial infarction and previous cryptogenic stroke caused by a paradoxical embolism with a concomitant pulmonary embolism. J Geriatr Cardiol. 2017;14:421-4. Available from: https://doi.org/10.11909/j.issn. 1671-5411.2017.06.003.

84. Doyen D, Castellani M, Moceri P, Chiche O, Lazdunski R, Bertora $\mathrm{D}$, et al. Patent foramen ovale and stroke in intermediaterisk pulmonary embolism. Chest. 2014;146:967-73. Available from: https://doi.org/10.1378/chest.14-0100.

85. Goliszek S, Wiśniewska M, Kurnicka K, Lichodziejewska B, Ciurzyński M, Kostrubiec M, et al. Patent foramen ovale increases the risk of acute ischemic stroke in patients with acute pulmonary embolism leading to right ventricular dysfunction. Thromb Res. 2014;134:1052-6. Available from: https://doi.org/ 10.1016/j.thromres.2014.09.013.

86. Clergeau M-R, Hamon M, Morello R, Saloux E, Viader F, Hamon M. Silent cerebral infarcts in patients with pulmonary embolism and a patent foramen ovale: a prospective diffusionweighted MRI study. Stroke. 2009;40:3758-62. Available from: https://doi.org/10.1161/STROKEAHA.109.559898.

87. Windecker S, Stortecky S, Meier B. Paradoxical embolism. J Am Coll Cardiol. 2014;64:403-15. Available from: https://doi.org/ 10.1016/j.jacc.2014.04.063.

88. Mojadidi MK, Christia P, Salamon J, Liebelt J, Zaman T, Gevorgyan R, et al. Patent foramen ovale: Unanswered questions. Eur J Intern Med. 2015;26:743-51. Available from: https://doi.org/ 10.1016/j.ejim.2015.09.017.

89. Ueno Y, Shimada Y, Tanaka R, Miyamoto N, Tanaka Y, Hattori $\mathrm{N}$, et al. Patent foramen ovale with atrial septal aneurysm may contribute to white matter lesions in stroke patients. Cerebrovasc Dis. 2010;30:15-22. Available from: https://doi.org/10.1159/ 000313439.

90.• Le Moigne E, Timsit S, Ben Salem D, Didier R, Jobic Y, Paleiron N, et al. Patent foramen ovale and ischemic stroke in patients with pulmonary embolism: A prospective cohort study. Ann Intern Med. 2019;170:756-63. Available from: https:// doi.org/10.7326/M18-3485. One of the largest prospective study evaluating the risk of stroke in patients with PFO and symptomatic PE suggesting the importance of paradoxical embolism.

91. Saric M, Armour AC, Arnaout MS, Chaudhry FA, Grimm RA, Kronzon I, et al. Guidelines for the Use of Echocardiography in the Evaluation of a Cardiac Source of Embolism. J Am Soc Echocardiogr. 2016;29:1-42. Available from: https://doi.org/10. 1016/j.echo.2015.09.011.

92. Holmes M, Rathbone J, Littlewood C, Rawdin A, Stevenson M, Stevens J, et al. Routine echocardiography in the management of stroke and transient ischaemic attack: a systematic review and economic evaluation. Health Technol Assess. 2014;18:1-176. Available from: https://doi.org/10.3310/hta18160.

93. Powers WJ. Clinical utility of echocardiography in secondary ischemic stroke prevention. Handb Clin Neurol. 2021;177:35975. Available from: https://doi.org/10.1016/B978-0-12-8198148.00022-6.

94. Rodrigues AC, Picard MH, Carbone A, Arruda AL, Flores T, Klohn J, et al. Importance of adequately performed Valsalva maneuver to detect patent foramen ovale during transesophageal echocardiography. J Am Soc Echocardiogr. 2013;26:1337-43. Available from: https://doi.org/10.1016/j.echo.2013.07.016.

95.• Zietz A, Sutter R, De Marchis GM. Deep vein thrombosis and pulmonary embolism among patients with a cryptogenic stroke 
linked to patent foramen ovale-A review of the literature. Front Neurol. 2020;11:336. Available from: https://doi.org/10.3389/ fneur.2020.00336. A literature review correlating the DVT, $\mathrm{PE}$ and PFO to Cryptogenic stroke.

96. Kim BJ, Sohn H, Sun BJ, Song J-K, Kang D-W, Kim JS, et al. Imaging characteristics of ischemic strokes related to patent foramen ovale. Stroke. 2013;44:3350-6. Available from: https:// doi.org/10.1161/STROKEAHA.113.002459.

97. Hart RG, Diener H-C, Coutts SB, Easton JD, Granger CB, O'Donnell MJ, et al. Embolic strokes of undetermined source: the case for a new clinical construct. Lancet Neurol. 2014;13:429-38. Available from: https://doi.org/10.1016/S14744422(13)70310-7.

98. Meissner I, Khandheria BK, Heit JA, Petty GW, Sheps SG, Schwartz GL, et al. Patent foramen ovale: innocent or guilty? Evidence from a prospective population-based study. J Am Coll Cardiol. 2006;47:440-5. Available from: https://doi.org/10. 1016/j.jacc.2005.10.044.

99. Handke M, Harloff A, Olschewski M, Hetzel A, Geibel A. Patent foramen ovale and cryptogenic stroke in older patients. N Engl J Med. 2007;357:2262-8. Available from: https://doi.org/10.1056/ NEJMoa071422.

100. Lechat P, Mas JL, Lascault G, Loron P, Theard M, Klimczac M, et al. Prevalence of patent foramen ovale in patients with stroke. N Engl J Med. 1988;318:1148-52. Available from: https://doi. org/10.1056/NEJM198805053181802.

101. Di Tullio M, Sacco RL, Gopal A, Mohr JP, Homma S. Patent foramen ovale as a risk factor for cryptogenic stroke. Ann Intern Med. 1992;117:461-5. Available from: https://doi.org/10.7326/ 0003-4819-117-6-461.

102. Ozdemir AO, Tamayo A, Munoz C, Dias B, Spence JD. Cryptogenic stroke and patent foramen ovale: clinical clues to paradoxical embolism. J Neurol Sci. 2008;275:121-7. Available from: https://doi.org/10.1016/j.jns.2008.08.018.

103. Schneck MJ. Neurologic complications of venous thromboembolism. Handb Clin Neurol. 2021;177:261-7. Available from: https://doi.org/10.1016/B978-0-12-819814-8.00017-2.

104. Saver JL, Carroll JD, Thaler DE, Smalling RW, MacDonald LA, Marks DS, et al. Long-Term Outcomes of Patent Foramen Ovale Closure or Medical Therapy after Stroke. N Engl J Med. 2017;377:1022-32. Available from: https://doi.org/10.1056/ NEJMoa1610057.

105. Mas J-L, Derumeaux G, Guillon B, Massardier E, Hosseini H, Mechtouff L, et al. Patent Foramen Ovale Closure or Anticoagulation vs. Antiplatelets after Stroke. N Engl J Med. 2017;377:1011-21. Available from: https://doi.org/10.1056/ NEJMoa1705915.

106. Søndergaard L, Kasner SE, Rhodes JF, Andersen G, Iversen HK, Nielsen-Kudsk JE, et al. Patent Foramen Ovale Closure or Antiplatelet Therapy for Cryptogenic Stroke. N Engl J Med. 2017;377:1033-42. Available from: https://doi.org/10.1056/ NEJMoa1707404

107. Shah R, Nayyar M, Jovin IS, Rashid A, Bondy BR, Fan T-HM, et al. Device closure versus medical therapy alone for patent foramen ovale in patients with cryptogenic stroke: A systematic review and meta-analysis. Ann Intern Med. 2018;168:335-42. Available from: https://doi.org/10.7326/M17-2679. This systematic review and meta-analysis concluded that in patients with PFO and cryptogenic stroke, transcatheter device closure decreases risk for recurrent stroke compared with medical therapy alone.

108. Stevkova Z, Krastev G, Mako M, Haring J, Benova L, Zajickova I, et al. May-thurner syndrome - Analysis of the group of the patients. Cerebrovasc Dis. 2014;37.

109. Harbin MM, Lutsey PL. May-Thurner syndrome: History of understanding and need for defining population prevalence. $\mathbf{J}$
Thromb Haemost. 2020. Available from: https://doi.org/10.1111/ jth.14707. This article emphasizes that the contribution of MTS to the development of DVT is likely undervalued in the setting of other more easily recognizable risk factors and difficulties surrounding diagnosis of MTS.

110. Kiernan TJ, Yan BP, Cubeddu RJ, Rengifo-Moreno P, Gupta V, Inglessis I, et al. May-Thurner syndrome in patients with cryptogenic stroke and patent foramen ovale: an important clinical association. Stroke. 2009;40:1502-4. Available from: https://doi. org/10.1161/STROKEAHA.108.527366.

111. Prabhakar AM, Misono AS, Brinegar KN, Khademhosseini A, Oklu R. Use of Magnetic Resonance Venography in Screening Patients With Cryptogenic Stroke for May-Thurner Syndrome. Curr Probl Diagn Radiol. 2016;45:370-2. Available from: https://doi.org/10.1067/j.cpradiol.2016.04.006.

112. COVID-19 Map - Johns Hopkins Coronavirus Resource Center. [cited 2021 Apr 3]. Available from: https://coronavirus.jhu.edu/ map.html.

113. Piazza G, Morrow DA. Diagnosis, management, and pathophysiology of arterial and venous thrombosis in COVID-19. JAMA. 2020;324:2548-9. Available from: https://doi.org/10.1001/jama. 2020.23422

114. Klok FA, Kruip MJHA, van der Meer NJM, Arbous MS, Gommers DAMPJ, Kant KM, et al. Incidence of thrombotic complications in critically ill ICU patients with COVID-19. Thromb Res. 2020;191:145-7. Available from: https://doi.org/10.1016/j. thromres.2020.04.013.

115. Siow I, Lee KS, Zhang JJY, Saffari SE, Ng A, Young B. Stroke as a neurological complication of COVID-19: A systematic review and meta-analysis of incidence, outcomes and predictors: Stroke and COVID-19. J Stroke Cerebrovasc Dis. 2021;30. Available from: https://doi.org/10.1016/j.jstrokecerebrovasdis. 2020.105549. This review described the epidemiology and clinical outcomes of patients who suffered a stroke as a complication of Covid-19.

116. Hess DC, Eldahshan W, Rutkowski E. COVID-19-Related Stroke. Transl Stroke Res. 2020;11:322-5. Available from: https://doi.org/10.1007/s12975-020-00818-9.

117. Blom JW, Doggen CJM, Osanto S, Rosendaal FR. Malignancies, prothrombotic mutations, and the risk of venous thrombosis. $\mathrm{J}$ Am Med Assoc. 2005;293. Available from: https://doi.org/10. 1001/jama.293.6.715.

118. Falanga A, Marchetti M, Russo L. The mechanisms of cancerassociated thrombosis. Thromb Res. 2015;135. Available from: https://doi.org/10.1016/S0049-3848(15)50432-5.

119. Razak NBA, Jones G, Bhandari M, Berndt MC, Metharom P. Cancer-associated thrombosis: An overview of mechanisms, risk factors, and treatment. Cancers. 2018. Available from: https:// doi.org/10.3390/cancers 10100380 .

120. Navi BB, Reiner AS, Kamel H, Iadecola C, Okin PM, Elkind MSV, et al. Risk of arterial thromboembolism in patients with cancer. J Am Coll Cardiol. 2017;70. Available from: https://doi. org/10.1016/j.jacc.2017.06.047.

121. Bao L, Zhang S, Gong X, Cui G. Trousseau syndrome related cerebral infarction: clinical manifestations, laboratory findings and radiological features. J Stroke Cerebrovasc Dis. 2020;29. Available from: https://doi.org/10.1016/j.jstrokecerebrovasdis. 2020.104891. Patients with cerebral infarcts secondary to Trousseau syndrome usually have a more severe neurologic deficit at the onset of stroke and worse clinical outomes.

122. Umemura T, Yamamoto J, Akiba D, Nishizawa S. Bilateral cerebral embolism as a characteristic feature of patients with Trousseau syndrome. J Clin Neurosci. 2017;42. Available from: https://doi.org/10.1016/j.jocn.2017.04.014.

123. Finelli PF, Nouh A. Three-Territory DWI acute infarcts: Diagnostic value in cancer-Associated hypercoagulation stroke 
(trousseau syndrome). AJNR Am J Neuroradiol. 2016;37. Available from: https://doi.org/10.3174/ajnr.A4846.

124. Nouh AM, Staff, Ilene, Finelli PF. Three territory sign: An MRI marker of malignancy-related ischemic stroke (Trousseau syndrome). Neurol Clin Pract. 2019;9. Available from: https://doi. org/10.1212/CPJ.0000000000000603.

125. Okazaki K, Oka F, Ishihara H, Suzuki M. Cerebral infarction associated with benign mucin-producing adenomyosis: Report of two cases. BMC Neurol. 2018;18. Available from: https://doi. org/10.1186/s12883-018-1169-2.

126. Wun T, White RH. Epidemiology of cancer-related venous thromboembolism. Best Pract Res: Clin Haematol. 2009. Available from: https://doi.org/10.1016/j.beha.2008.12.001.

127. Horsted F, West J, Grainge MJ. Risk of venous thromboembolism in patients with cancer: A systematic review and metaanalysis. PLoS Med. 2012. Available from: https://doi.org/10. 1371/journal.pmed.1001275.

128. Riedl J, Preusser M, Nazari PMS, Posch F, Panzer S, Marosi C, et al. Podoplanin expression in primary brain tumors induces platelet aggregation and increases risk of venous thromboembolism. Blood. 2017;129. Available from: https://doi.org/10.1182/ blood-2016-06-720714.

$129 . \bullet$ Riedl J, Ay C. Venous thromboembolism in brain tumors: Risk factors, molecular mechanisms, and clinical challenges. Semin Thromb Hemost. 2019;45. Available from: https://doi.org/10. 1055/s-0039-1688493. Brain tumors with the wild-type IDH1 gene express podoplanin that stimulates platelet activation and triggers venous thrombosis.

130. Mir Seyed Nazari P, Riedl J, Preusser M, Posch F, Thaler J, Marosi C, et al. Combination of isocitrate dehydrogenase 1 (IDH1) mutation and podoplanin expression in brain tumors identifies patients at high or low risk of venous thromboembolism. J Thromb Haemost. 2018;16. Available from: https://doi. org/10.1111/jth.14129.

131. Marras LC, Geerts WH, Perry JR. The risk of venous thromboembolism is increased throughout the course of malignant glioma: An evidence-based review. Cancer. 2000;89. Available from: https://doi.org/10.1002/1097-0142(20000801)89:3<640:: AID-CNCR20>3.0.CO;2-E.

132. Simanek R, Vormittag R, Hassler M, Roessler K, Schwarz M, Zielinski C, et al. Venous thromboembolism and survival in patients with high-grade glioma. Neuro Oncol. 2007;9. Available from: https://doi.org/10.1215/15228517-2006-035.

133. Streiff MB, Segal J, Grossman SA, Kickler TS, Weir EG. ABO Blood Group is a potent risk factor for venous thromboembolism in patients with malignant gliomas. Cancer. 2004. Available from: https://doi.org/10.1002/cncr.20150.

134. Semrad TJ, O'Donnell R, Wun T, Chew H, Harvey D, Zhou $\mathrm{H}$, et al. Epidemiology of venous thromboembolism in 9489 patients with malignant glioma. J Neurosurg. 2007;106. Available from: https://doi.org/10.3171/jns.2007.106.4.601.

135. Castelli R, Tarsia P, Tantardini C, Pantaleo G, Guariglia A, Porro F. Syncope in patients with pulmonary embolism: comparison between patients with syncope as the presenting symptom of pulmonary embolism and patients with pulmonary embolism without syncope. Vasc Med. 2003;8:257-61. Available from: https://doi.org/10.1191/1358863x03vm510oa.

136. Mark AL. The Bezold-Jarisch reflex revisited: clinical implications of inhibitory reflexes originating in the heart. J Am Coll Cardiol. 1983;1:90-102. Available from: https://doi.org/10. 1016/s0735-1097(83)80014-x.

137. Aviado DM, Guevara Aviado D. The Bezold-Jarisch reflex. A historical perspective of cardiopulmonary reflexes. Ann N Y Acad Sci. 2001;940:48-58. Available from: https://www.ncbi. nlm.nih.gov/pubmed/11458703.
138. Sanchez O, Trinquart L, Caille V, Couturaud F, Pacouret G, Meneveau N, et al. Prognostic factors for pulmonary embolism: the prep study, a prospective multicenter cohort study. Am J Respir Crit Care Med. 2010;181:168-73. Available from: https:// doi.org/10.1164/rccm.200906-09700C.

139. Jiménez D, Aujesky D, Moores L, Gómez V, Martí D, Briongos $S$, et al. Combinations of prognostic tools for identification of high-risk normotensive patients with acute symptomatic pulmonary embolism. Thorax. 2011;66:75-81. Available from: https:// doi.org/10.1136/thx.2010.150656.

140. Bova C, Sanchez O, Prandoni P, Lankeit M, Konstantinides $S$, Vanni S, et al. Identification of intermediate-risk patients with acute symptomatic pulmonary embolism. Eur Respir J. 2014;44:694-703. Available from: https://doi.org/10.1183/ 09031936.00006114.

141. Hobohm L, Hellenkamp K, Hasenfuß G, Münzel T, Konstantinides S, Lankeit M. Comparison of risk assessment strategies for not-high-risk pulmonary embolism. Eur Respir J. 2016;47:1170-8. Available from: https://doi.org/10.1183/13993 003.01605-2015.

142. Altınsoy B, Erboy F, Tanrıverdi H, Uygur F, Örnek T, Atalay F, et al. Syncope as a presentation of acute pulmonary embolism. Ther Clin Risk Manag. 2016;12:1023-8. Available from: https:// doi.org/10.2147/TCRM.S105722.

143. Duplyakov D, Kurakina E, Pavlova T, Khokhlunov S, Surkova E. Value of syncope in patients with high-to-intermediate risk pulmonary artery embolism. Eur Heart J Acute Cardiovasc Care. 2015;4:353-8. Available from: https://doi.org/10.1177/20488 72614527837.

144. Huang C-M, Lin Y-C, Lin Y-J, Chang S-L, Lo L-W, Hu Y-F, et al. Risk stratification and clinical outcomes in patients with acute pulmonary embolism. Clin Biochem. 2011;44:1110-5. Available from: https://doi.org/10.1016/j.clinbiochem.2011.06. 077.

145. Calvo-Romero JM, Pérez-Miranda M, Bureo-Dacal P. Syncope in acute pulmonary embolism. Eur J Emerg Med. 2004;11:2089. Available from: https://doi.org/10.1097/01.mej.0000136696. 49343.8f.

146. Jiménez D, Díaz G, Valle M, Martí D, Escobar C, Vidal R, et al. Prognostic value of syncope in the presentation of pulmonary embolism. Arch Bronconeumol. 2005;41:385-8. Available from: https://doi.org/10.1016/s1579-2129(06)60246-2.

147. Jenab Y, Lotfi-Tokaldany M, Alemzadeh-Ansari M-J, Seyyedi SR, Shirani S, Soudaee M, et al. Correlates of syncope in patients with acute pulmonary thromboembolism. Clin Appl Thromb Hemost. 2015;21:772-6. Available from: https://doi. org/10.1177/1076029614540037.

148. Goldhaber SZ, Visani L, De Rosa M. Acute pulmonary embolism: clinical outcomes in the International Cooperative Pulmonary Embolism Registry (ICOPER). Lancet. 1999;353:1386-9. Available from: https://doi.org/10.1016/s0140-6736(98)07534-5.

149. • Barco S, Ende-Verhaar YM, Becattini C, Jimenez D, Lankeit M, Huisman MV, et al. Differential impact of syncope on the prognosis of patients with acute pulmonary embolism: a systematic review and meta-analysis. Eur Heart J. 2018;39:4186-95. Available from: https://doi.org/10.1093/eurheartj/ehy631. In this meta-analysis, the authors described various studies which found the association between syncope and PE versus those which didn't. Syncope had shown a higher prevalence of hemodynamic instability, echocardiographic changes along with higher prevalence of mortality.

150. Collado A, Villalta J, Bombí JA, Ingelmo M. Diagnostic and prognostic value of factors associated with pulmonary thromboembolism. Study of 70 autopsy cases. Med Clin. 1986;86:265-7. Available from: https://www.ncbi.nlm.nih.gov/pubmed/3713341. 
151. Goldhaber SZ, Hennekens CH, Evans DA, Newton EC, Godleski JJ. Factors associated with correct antemortem diagnosis of major pulmonary embolism. Am J Med. 1982;73:822-6. Available from: https://doi.org/10.1016/0002-9343(82)90764-1.

152. Sarasin FP, Louis-Simonet M, Carballo D, Slama S, Rajeswaran A, Metzger JT, et al. Prospective evaluation of patients with syncope: a population-based study. Am J Med. 2001;111:177-84. Available from: https://doi.org/10.1016/s0002-9343(01)00797-5.

153. Freund Y, Philippon AL, Feral-Pierssens AL, Damas Perrichet C, Boussouar S, Donciu V, et al. Prevalence of pulmonary embolism in patients with isolated syncope in the emergency department: the PEEPS multicenter prospective cohort study. Pulmonary embolism. European Respiratory Society; 2019. Available from: http://erj.ersjournals.com/lookup/doi/10.1183/13993003. congress-2019.PA3645.

154. Richmond C, Jolly H, Isles C. Syncope in pulmonary embolism: a retrospective cohort study. Postgrad Med J. 2020. Available from: https://doi.org/10.1136/postgradmedj-2020-138677.

155. Ghuysen A, Ghaye B, Willems V, Lambermont B, Gerard P, Dondelinger RF, et al. Computed tomographic pulmonary angiography and prognostic significance in patients with acute pulmonary embolism. Thorax. 2005;60:956-61. Available from: https://doi.org/10.1136/thx.2005.040873.

156. Meneveau N, Ming LP, Séronde MF, Mersin N, Schiele F, Caulfield F, et al. In-hospital and long-term outcome after submassive and massive pulmonary embolism submitted to thrombolytic therapy. Eur Heart J. 2003;24:1447-54. Available from: https://doi.org/10.1016/s0195-668x(03)00307-5.

157. Fred HL, Yang M. Sudden loss of consciousness, dyspnea, and hypoxemia in a previously healthy young man. Circulation. 1995. Available from: https://doi.org/10.1161/01.CIR.91.12. 3017.

158. Marine JE, Goldhaber SZ. Pulmonary embolism presenting as seizures. Chest. 1997. Available from: https://doi.org/10.1378/ chest.112.3.840.

159. Kupnik D, Grmec Š. Pulmonary thromboembolism presenting as epileptiform generalized seizure. Eur J Emerg Med. 2004. Available from: https://doi.org/10.1097/00063110-200412000-00009.

160. Volz EEG, Jasani N. Seizure as a presentation of pulmonary embolism. J Emerg Med. 2014. Available from: https://doi.org/ 10.1016/j.jemermed.2013.08.057.

161.• Zuin M, Rigatelli G, Zuliani G, Adami A, Zonzin P, Roncon L. Seizures as the first clinical manifestation of acute pulmonary embolism: an underestimate issue in neurocritical care. Neurol Sci. 2020. Available from: https://doi.org/10.1007/s10072-02004275-y. A literature review of $\mathbf{2 5 8}$ articles analyzing pathophysiology, clinical presentation, treatment, and outcomes for patients with concomitant seizure and pulmonary embolism.

162. Pourshahid S, Dedhia S, Hakim S, Barakat M, Genin D. Seizure and Pulmonary Embolism: A Differential That Can Save a Life. Case Rep Pulmonol. 2017. Available from: https://doi.org/10. 1155/2017/3408795.

163. Kimura K, Mori H, Kitaguchi H, Yamao F, Shindo K. Pulmonary embolism as a cause of seizure. Am J Emerg Med. 2013. Available from: https://doi.org/10.1016/j.ajem.2013.06.024.

164. Baldwin MJ, Moore HM, Rudarakanchana N, Gohel M, Davies AH. Post-thrombotic syndrome: a clinical review. J Thromb Haemost. 2013;11:795-805. Available from: https://doi.org/10. $1111 /$ jth. 12180 .

165. Langeron P. Painful manifestations of the sequelae of phlebitis. Phlebologie. 1992;45:51-8; discussion 59-60. Available from: https://www.ncbi.nlm.nih.gov/pubmed/1496032.

166. Sahu KK, Mishra AK, Zhang P. Femoral Neuropathy: A Rare Presentation of Retroperitoneal Hematoma with Review of Literature. Indian J Hematol Blood Transfus. 2020;36:174-7. Available from: https://doi.org/10.1007/s12288-019-01126-5.

167. Qureshi AI, Babar S, Kherani D, Saleem MA, Qi L, Wallery SS, et al. Femoral Neuropathy Following Transfemoral Neuroendovascular Procedures. An Analysis of a Prospective Registry. J Neuroimaging. 2019;29:268-71. Available from: https://doi.org/ 10.1111/jon.12584.

168. Bendszus M, Reiners K, Perez J, Solymosi L, Koltzenburg M. Peroneal nerve palsy caused by thrombosis of crural veins. Neurology. 2002;58:1675-7. Available from: https://doi.org/ 10.1212/wnl.58.11.1675.

169. Hufeland M, Braun M, Marnitz T, Schroeder J, Lindner T. Peroneal nerve palsy due to thrombosis of a crural vein in a healthy young woman. Clin Neurol Neurosurg. 2013;115:487-9. Available from: https://doi.org/10.1016/j.clineuro.2012.06.012.

170. Bayramoglu A, Calmasur A, Akoz A, Saritemur M. A Rare Cause of Compression of the Ulnar Nerve Neuritis: Deep Vein Thrombosis. Turk J Emerg Med. 2014;14:97. Available from: https://doi.org/10.5505/1304.7361.2014.59319.

171. Nkele C. Acute carpal tunnel syndrome resulting from haemorrhage into the carpal tunnel in a patient on warfarin. J Hand Surg Br. 1986;11:455-6. Available from: https://doi.org/10. 1016/0266-7681(86)90181-6.

Publisher's Note Springer Nature remains neutral with regard to jurisdictional claims in published maps and institutional affiliations. 